\title{
Gambogic acid suppresses colon cancer cell activity in vitro
}

\author{
ZAILONG ZHOU $^{1}$ and JIAN MA ${ }^{2}$ \\ ${ }^{1}$ Department of Coloproctology, The First Affiliated Hospital of Nanjing University of Traditional Chinese Medicine, \\ Nanjing, Jiangsu 210029; ${ }^{2}$ Department of Coloproctology, The Basic Medical College, \\ Nanjing University of Traditional Chinese Medicine, Nanjing, Jiangsu 210023, P.R. China
}

Received June 28, 2018; Accepted December 21, 2018

DOI: $10.3892 /$ etm.2019.7912

\begin{abstract}
The aim of the present study was to elucidate the underlying mechanism of antitumor activity of gambogic acid (GA) in colon cancer. Human colon cancer SW620 cells were divided into five treatment groups, including no-treatment control (NC), low dose GA $(10 \mu \mathrm{g} / \mathrm{ml})$, medium dose GA $(50 \mu \mathrm{g} / \mathrm{ml})$, high dose GA $(100 \mu \mathrm{g} / \mathrm{ml})$ and 5-fluorouracil $(10 \mu \mathrm{g} / \mathrm{ml})$. Differences in cell proliferation, apoptosis and cell cycle, invasion, and migration were measured between groups using MTT, flow cytometry, transwell and wound-healing assays, respectively. Western blotting was used to analyze relative protein expression levels of phosphoinositide 3-kinase (PI3K), protein kinase B (AKT), P21, and matrix metalloprotease (MMP)-2 and -9 between groups. Compared with the NC group, GA (low, middle and high) inhibited SW620 cell proliferation, invasion and migration (all $\mathrm{P}<0.05$ ). Furthermore, there were significant differences in proliferation, invasion and migration between groups administered with different doses of GA (all $\mathrm{P}<0.05$ ). Compared with the NC group, the expression levels of PI3K, AKT, phosphorylated-AKT, P21 and MMP-2 and -9 were significantly altered in a dose dependent manner following treatment with GA (all $\mathrm{P}<0.05$ ). The results of the current study indicated that GA suppressed proliferation and dispersion of human colon cancer cells in a dose-dependent manner, possibly through a PI3K/AKT/P21/MMP-2/9-dependent pathway.
\end{abstract}

\section{Introduction}

Colon cancer is a common malignancy of the digestive tract with an increasing incidence each year (1). At present, 5 -fluorouracil (5-Fu)-based combination chemotherapy is considered the gold standard treatment; however, it is associated

Correspondence to: Dr Jian Ma, Department of Coloproctology, The Basic Medical College, Nanjing University of Traditional Chinese Medicine, 138 Xianlin Road, Nanjing, Jiangsu 210023, P.R. China

E-mail: majian1017@126.com

Key words: gambogic acid, colon cancer, phosphoinositide 3-kinase, protein kinase B, phosphorylated-protein kinase B, P21, matrix metalloproteinase-2 and -9, SW620 with significant side effects and poor tolerability (2). Despite the improved prognosis associated with the use of targeted drugs, the mortality rate remains high among patients with colon cancer, and there is an evident clinical requirement for new treatment methods (3). Gambogic acid (GA), a bioactive compound extracted from certain Garcinia species, exhibits a variety of antitumor activities against several types of cancer (4-6). The limited information available suggests that GA may inhibit colon cancer by suppressing cellular activities, including proliferation, apoptosis, invasion and migration (7).

The phosphoinositide 3-kinase (PI3K)/protein kinase $\mathrm{B}$ (AKT) pathway is an important signaling pathway in cell development and growth (8-10). Previous studies revealed that suppressing the PI3K/AKT signaling pathway may inhibit cancer cell proliferation and increase cancer cell apoptosis by regulating P21 expression $(11,12)$. Other studies confirmed that inhibition of the PI3K/AKT signaling pathway may suppress cancer cell invasion and migration, possibly by regulating matrix metalloprotease (MMP)-2 and -9 expression $(13,14)$. The current study evaluated the antitumor effect of GA and the underlying mechanism in a human colon cancer cell line.

\section{Materials and methods}

Cells and reagents. Human colon cancer cell line SW620 was purchased from American Type Culture Collection (Manassas, VA, USA). Fetal bovine serum (FBS), RPMI-1640 medium and pancreatin were purchased from Hyclone (GE Healthcare Life Sciences, Logan, UT, USA). GA (purity, $\geq 95 \%$ ) was purchased from Chengdu Pulis Biotech Co., Ltd. (Chengdu, China). MTT, dimethylsulfoxide (DMSO) and 5-Fu were purchased from Sigma-Aldrich (Merck KGaA, Darmstadt, Germany), while the Annexin V-fluorescein isothiocyanate (FITC)/propudium iodide (PI) apoptosis and cell cycle assay kits [Cell cycle and apoptosis (PI) kit] were purchased from BD Biosciences (San Jose, CA, USA). Antibodies against PI3K (1:500; cat. no. ab32089), AKT (1:500; cat. no. ab8805), phosphorylated (p)-AKT (1:500; cat. no. ab8933), P21 (1:500; cat. no. ab109520), MMP-2 (1:500; cat. no. ab37150), MMP-9 (1:500; cat. no. ab73734) and GAPDH (1:1,000; cat. no. ab181602) were purchased from Abcam (Cambridge, MA, USA). Furthermore, a DM3000 microscope (Leica Microsystems GmbH, Wetzlar, Germany) and LightCycler ${ }^{\circledR}$ 480 instrument (Roche Molecular Diagnostics, Pleasanton, CA, USA) were used in the present study. 
Cell culture and experimental design. SW620 cells were cultured in RPMI-1640 medium with 10\% FBS in an incubator at $37^{\circ} \mathrm{C}$ and $5 \% \mathrm{CO}_{2}$ and passaged upon reaching $90 \%$ confluence. The culture was divided into five groups based on subculturing conditions: i) No-treatment control (NC) group cultured in RPMI-1640 medium with $10 \%$ FBS; ii) NC group medium $+10 \mu \mathrm{g} / \mathrm{ml}$ GA (low group); iii) NC group medium $+50 \mu \mathrm{g} / \mathrm{ml}$ GA (medium group); iv) NC group medium $+100 \mu \mathrm{g} / \mathrm{ml} \mathrm{GA}$ (high group); and v) NC group medium $+10 \mu \mathrm{g} / \mathrm{ml}$ 5-Fu (5-Fu group). Cells were cultured in their respective experimental group media as described below for each specific assay. Cells were cultured until the logarithmic growth stage and digested with trypsin prior to seeding into culture plates for specific experiments.

MTT assay. A $200-\mu 1$ cell suspension $\left(4 \times 10^{3}\right.$ cells $\left./ \mathrm{ml}\right)$ was cultured in 6-well-plates for $5 \mathrm{~h}$ to allow time for cell adherence, after which the medium was replaced with the group-specific experimental culture media, as described above. Each group was cultured in triplicate. After $48 \mathrm{~h}$ at room temperature, $20 \mu 1 \mathrm{MTT}(5 \mathrm{~g} / \mathrm{ml})$ was added to each well and the plates were cultured for $30 \mathrm{~h}$ at room temperature. DMSO was added to each well to stop the reaction, and the OD value was measured at $490 \mathrm{~nm}$ on the plate reader to calculate cell proliferation.

Apoptosis assay. SW620 cells $\left(1 \times 10^{6} \mathrm{cells} / \mathrm{ml}\right)$ were seeded in a 6 -well plate ( $2 \mathrm{ml} /$ well) and cultured for $24 \mathrm{~h}$ in group-specific media at room temperature. Media were removed and cells collected by resuspending in $300 \mu \mathrm{l}$ binding buffer, to which $5 \mu \mathrm{l}$ Annexin V-FITC was added according to the manufacturer's protocol. Suspensions were incubated at room temperature in the dark for $15 \mathrm{~min}$, after which $5 \mu \mathrm{l}$ PI was added. Apoptosis was detected by flow cytometry (FACSAria; BD Biosciences; wavelength, $488 \mathrm{~nm}$ ) supplemented with $200 \mu 11 \mathrm{X}$ binding buffer (diluted in double distilled water) at room temperature after $1 \mathrm{~h}$. All tests were performed in triplicate. Data were analyzed using Diva software (version 8.0.1; FACSAria; BD Biosciences).

Cell cycle assay. SW620 cells in the logarithmic growth phase were seeded in a $7.5-\mathrm{cm}$ culture flask and cultured for $24 \mathrm{~h}$, then digested by pancreatin and pelleted by centrifugation $\left(1,000 \mathrm{x} \mathrm{g}\right.$ at $4^{\circ} \mathrm{C}$ for $\left.5 \mathrm{~min}\right)$. Cell cycle status was detected using the aforementioned cell cycle kit according to the manufacturer's protocol. Briefly, the cells of each group were treated with their respective aforementioned conditioned media for $24 \mathrm{~h}$ at room temperature. Afterwards, $5 \mu \mathrm{l}$ RNase $(10 \mathrm{mg} / \mathrm{ml})$ was added to the PBS-resuspended cell pellet, and the cells were cultured at room temperature for $1 \mathrm{~h}$. PI $(100 \mu \mathrm{g} / \mathrm{ml})$ was subsequently added and the cells incubated at room temperature for $30 \mathrm{~min}$. The cell cycle status was measured in triplicate by flow cytometry (FACSAria; BD Biosciences) at a wavelength of $488 \mathrm{~nm}$ and data were analyzed using Diva software (version 8.0.1; FACSAria; BD Biosciences).

Transwell invasion assay. Matrigel (1:3) was diluted with serum-free medium (RPMI-1640) and placed in the upper transwell chamber (pore size, $8 \mu \mathrm{m}$ ) at $37^{\circ} \mathrm{C}$ for $4 \mathrm{~h}$, after which the transwell chambers were placed in 24 -well plates. SW620 cells ( $1 \times 10^{4}$ cells/ml; $100 \mu \mathrm{l} /$ well cell suspension) from each individual experimental group were added to the upper chamber. Complete culture medium (RPMI-1640) containing $10 \%$ FBS was added to the lower chamber, and the cells were cultured for $24 \mathrm{~h}$. Subsequently, noninvasive cells were removed with cotton swabs. The transwell chambers were removed from the wells, washed with phosphate-buffered saline (PBS) three times and the remaining cells in the lower chamber were fixed with $4 \%$ paraformaldehyde-PBS solution for $10 \mathrm{~min}$ at room temperature. The chambers were subsequently washed with PBS as aforementioned, inverted and dried. Cells were stained with $0.1 \%$ cresyl violet solution for $20 \mathrm{~min}$ at room temperature and washed with PBS three times. Cells were subsequently counted under an inverted optical microscope.

Wound healing assay. SW620 cells (5x104/well) from each experimental group were seeded into a six-well plate and cultured for $24 \mathrm{~h}$ at room temperature. When the cells formed a single, tightly adherent layer, a scraper with a 2 -mm wide tip was used to scratch the confluent cells. Images of each scratch were captured under a light microscope at $0 \mathrm{~h}$. Plates were cultured and images were captured again under the light microscope at $48 \mathrm{~h}$. Image-Pro Plus software (version 6.0; Media Cybernetics, Inc., Rockville, MD, USA) was used to measure the scratch width in the 0 - and 48-h images and to calculate the cell migration rate from the difference.

Western blotting. Cells were incubated for $24 \mathrm{~h}$ at room temperature in the aforementioned conditioned media and collected using lysis buffer (Beyotime Institute of Biotechnology) and the protein concentration was measured using a bicinchoninic acid Protein kit (Beyotime Institute of Biotechnology). Subsequently, cells of the different groups were washed three times with ice-cold PBS and lysed with buffer containing $50 \mathrm{mM}$ Tris- $\mathrm{HCl}$ (pH 7.6), $150 \mathrm{mM} \mathrm{NaCl}, 1 \mathrm{mM}$ EDTA, $1 \%$ NP-40, $0.5 \%$ Na-deoxycholate, $5 \mu \mathrm{g} / \mathrm{ml}$ aprotinin, $5 \mu \mathrm{g} / \mathrm{ml}$ leupeptin and $1 \mathrm{mM}$ phenylmethylsulphonyl fluoride. Cell lysates were cleared via centrifugation at $12,000 \mathrm{x} \mathrm{g}$ at $4^{\circ} \mathrm{C}$ for $30 \mathrm{~min}$ and denatured by boiling in Laemmli buffer (Beyotime Institute of Biotechnology). Proteins were denatured by incubation in a boiling water bath for 5 min with $5 \mathrm{X}$ SDS gel buffer solution. A total of $15 \mu 1 /$ lane of each sample was electrophoresed on an 8\% SDS-PAGE (110V; $4 \mathrm{~h}$ ). The protein samples were transferred to polyvinylidene fluoride (PVDF) membranes using the semi-dry method. The PVDF membranes were blocked with 5\% skim milk in PBS for $1.5 \mathrm{~h}$ at room temperature. The membranes were subsequently incubated with the aforementioned primary antibodies overnight at $4^{\circ} \mathrm{C}$. Following this incubation, the membrane was washed three times in PBS and incubated in goat anti-rabbit second antibody (1:5,000; cat. no. ab205718; Abcam) solution at room temperature for $2 \mathrm{~h}$. Anti-GAPDH antibody was used as an internal reference. Specific immune complexes were detected using the Western Blotting Plus Chemiluminescence Reagent (Thermo Fisher Scientific, Inc.). Band intensity was quantified via densitometry analysis using Image-Pro Plus version 4.5 software (Media Cybernetics, Inc.).

Statistical analysis. Data are presented as the mean \pm standard deviation from three independent experiments. Quantitative results were analyzed via one-way ANOVA assay followed by 


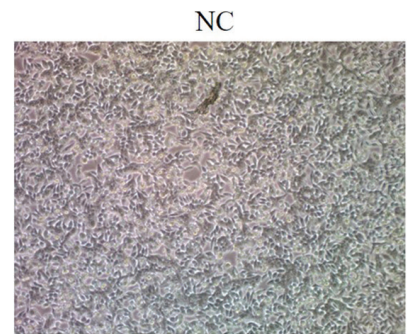

High

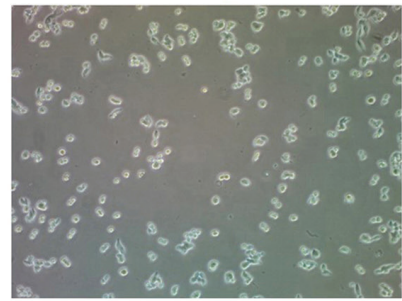

Low

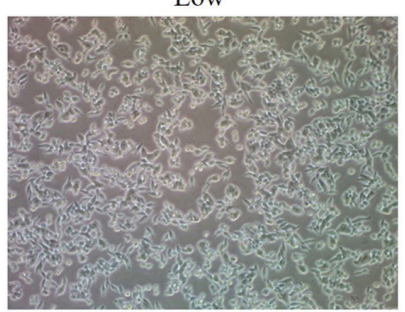

$5-\mathrm{Fu}$

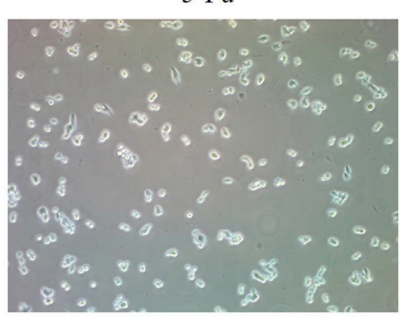

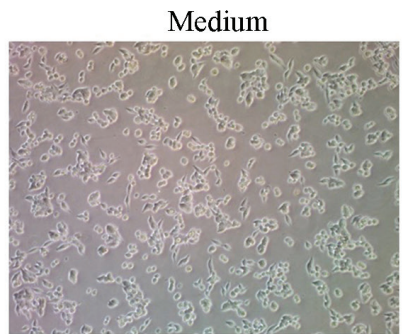

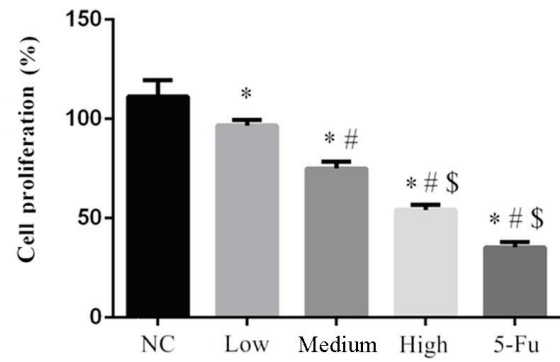

Figure 1. Cell proliferation rate among different groups (magnification, $\mathrm{x} 100$ ). ${ }^{*} \mathrm{P}<0.05$ vs. the NC group; ${ }^{\#} \mathrm{P}<0.05$ vs. the low group; ${ }^{\mathrm{s}} \mathrm{P}<0.05$ vs. the medium group. NC, no-treatment control group; low, group treated with $10 \mu \mathrm{g} / \mathrm{ml} \mathrm{GA}$; medium, group treated with $50 \mu \mathrm{g} / \mathrm{ml} \mathrm{GA}$; high, group treated with $100 \mu \mathrm{g} / \mathrm{ml}$ $\mathrm{GA} ; 5$-Fu, group treated with $10 \mu \mathrm{g} / \mathrm{ml}$ 5-fluorouracil; GA, gambogic acid.
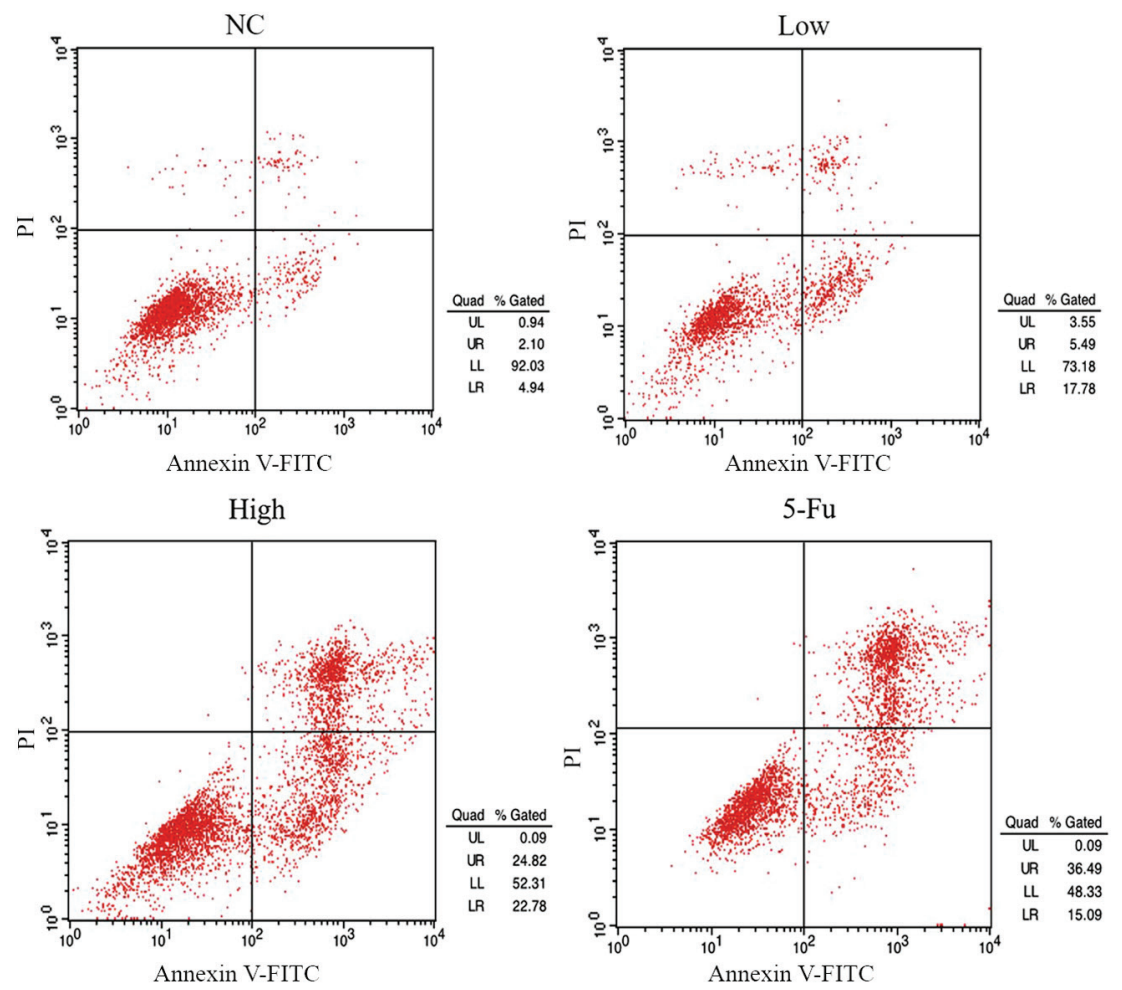
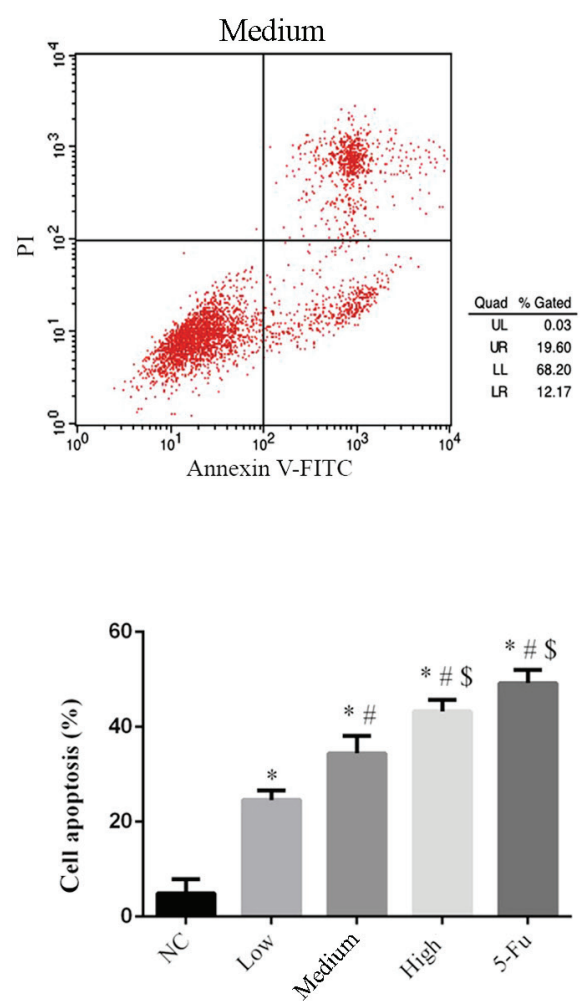

Figure 2. Cell apoptosis rate of different groups. ${ }^{~} \mathrm{P}<0.05$ vs. the NC group; ${ }^{*} \mathrm{P}<0.05$ vs. the low group; ${ }^{\mathrm{S}} \mathrm{P}<0.05$ vs. the medium group. NC, no-treatment control group; low, group treated with $10 \mu \mathrm{g} / \mathrm{ml} \mathrm{GA}$; medium, group treated with $50 \mu \mathrm{g} / \mathrm{ml} \mathrm{GA}$; high, group treated with $100 \mu \mathrm{g} / \mathrm{ml} \mathrm{GA} ; 5$-Fu, group treated with $10 \mu \mathrm{g} / \mathrm{ml}$ 5-fluorouracil; GA, gambogic acid.

a Tukey's post hoc test. $\mathrm{P}<0.05$ was considered to indicate a statistically significant difference.

\section{Results}

GA suppresses cell proliferation. Cell proliferation rates of the GA-treated groups were significantly suppressed compared with the $\mathrm{NC}$ group (all $\mathrm{P}<0.05$ ). The proliferation rate of $5-\mathrm{Fu}$ treated cells was significantly suppressed when compared with the NC, low and medium groups (each, $\mathrm{P}<0.05$ ). Furthermore, significant differences in proliferation rates were identified between the GA-treated groups (low, medium and high; all $\mathrm{P}<0.05$; Fig. 1).

GA influences cell apoptosis rates. Compared with the $\mathrm{NC}$ group, apoptosis rates in all GA-treated groups were 

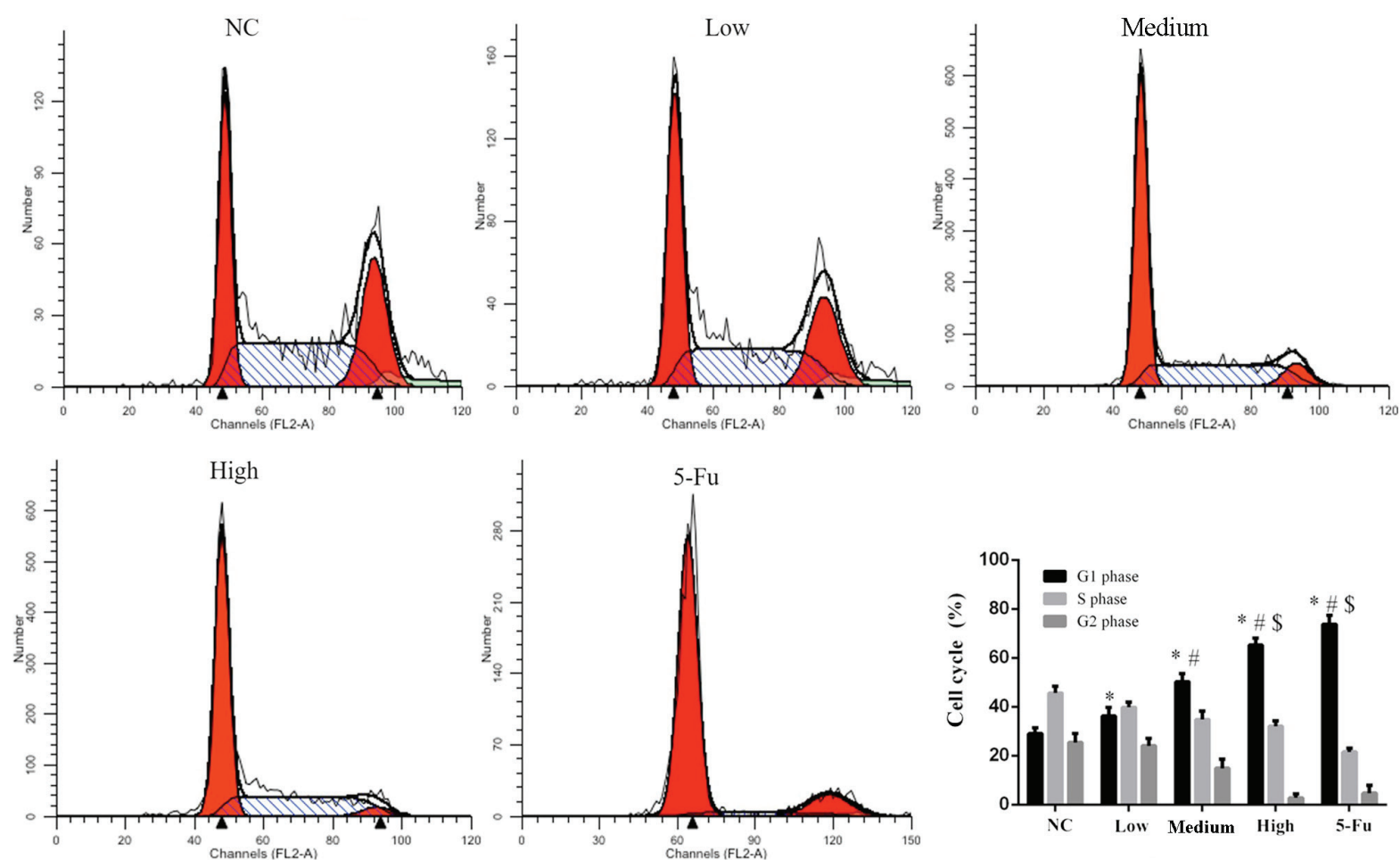

Figure 3. Cell cycle of different groups. ${ }^{*} \mathrm{P}<0.05$ vs. the $\mathrm{NC}$ group; ${ }^{*} \mathrm{P}<0.05$ vs. the low group; ${ }^{ } \mathrm{P}<0.05$ vs. the medium group. NC, no-treatment control group; low, group treated with $10 \mu \mathrm{g} / \mathrm{ml} \mathrm{GA}$; medium, group treated with $50 \mu \mathrm{g} / \mathrm{ml} \mathrm{GA}$; high, group treated with $100 \mu \mathrm{g} / \mathrm{ml} \mathrm{GA} ; 5$-Fu, group treated with $10 \mu \mathrm{g} / \mathrm{ml}$ 5-fluorouracil; GA, gambogic acid.
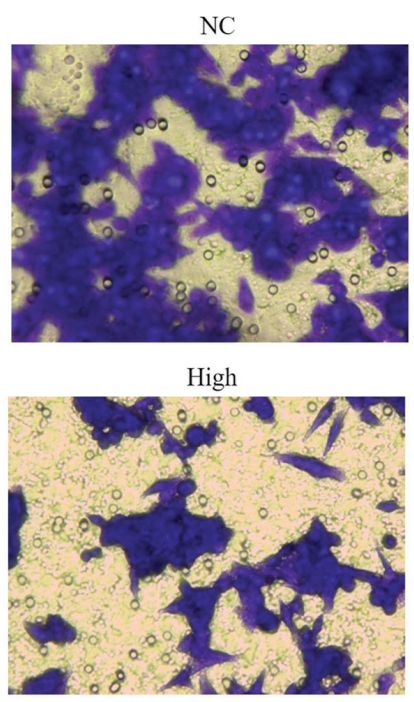
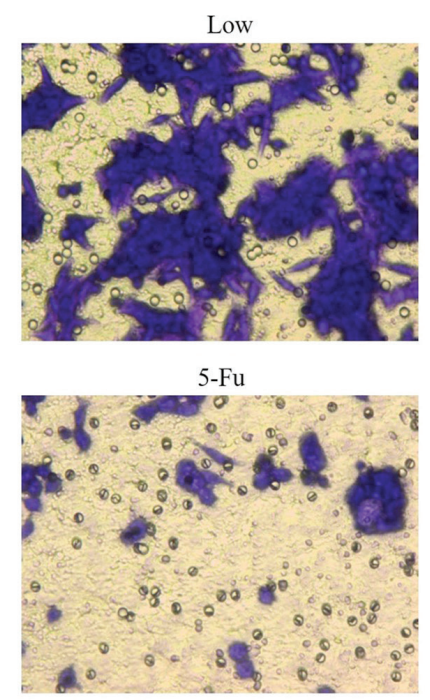
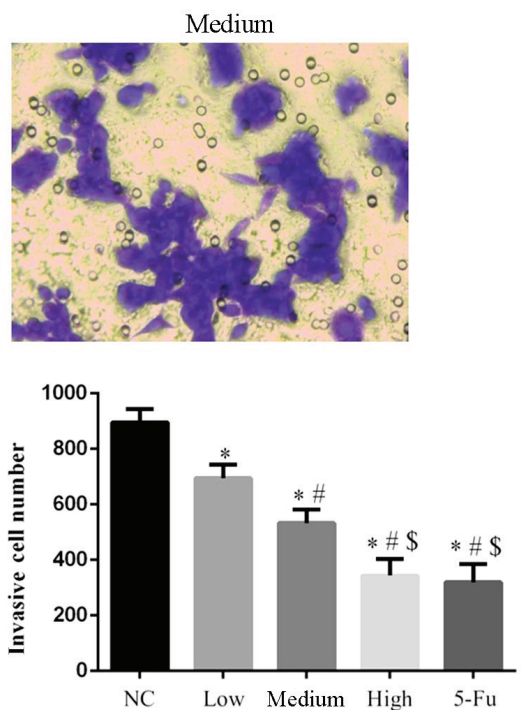

Figure 4. Invasive cell number determined in different groups using transwell assay (magnification, $\mathrm{x} 200$ ). ${ }^{*} \mathrm{P}<0.05$ vs. the $\mathrm{NC}$ group; ${ }^{*} \mathrm{P}<0.05$ vs. the low group; ${ }^{\$} \mathrm{P}<0.05$ vs. the medium group. NC, no-treatment control group; low, group treated with $10 \mu \mathrm{g} / \mathrm{ml} \mathrm{GA}$; medium, group treated with $50 \mu \mathrm{g} / \mathrm{ml} \mathrm{GA}$; high, group treated with $100 \mu \mathrm{g} / \mathrm{ml} \mathrm{GA} ; 5$-Fu, group treated with $10 \mu \mathrm{g} / \mathrm{ml} 5$-fluorouracil; GA, gambogic acid.

significantly upregulated $(\mathrm{P}<0.05$; Fig. 2). The rates of apoptosis increased in a dose-dependent manner. The apoptosis rate of the 5-Fu group was significantly upregulated compared with the $\mathrm{NC}$, low and medium groups (each, $\mathrm{P}<0.05$; Fig. 2).

GA affects the cell cycle. A significantly increased number of G1-phase cells was observed among GA treated groups compared with the NC group (all $\mathrm{P}<0.05$; Fig. 3 ). The number of 5-Fu treated cells in the G1 phase were significantly increased compared with the $\mathrm{NC}$, low and medium groups (each, $\mathrm{P}<0.05$; Fig. 3 ). The increase in the number of G1-phase cells was dose dependent and the differences between GA-treated groups were statistically significant $(\mathrm{P}<0.05)$.

GA suppresses cell invasion. Counts of invasive cells were significantly lower in all GA groups compared with the NC 

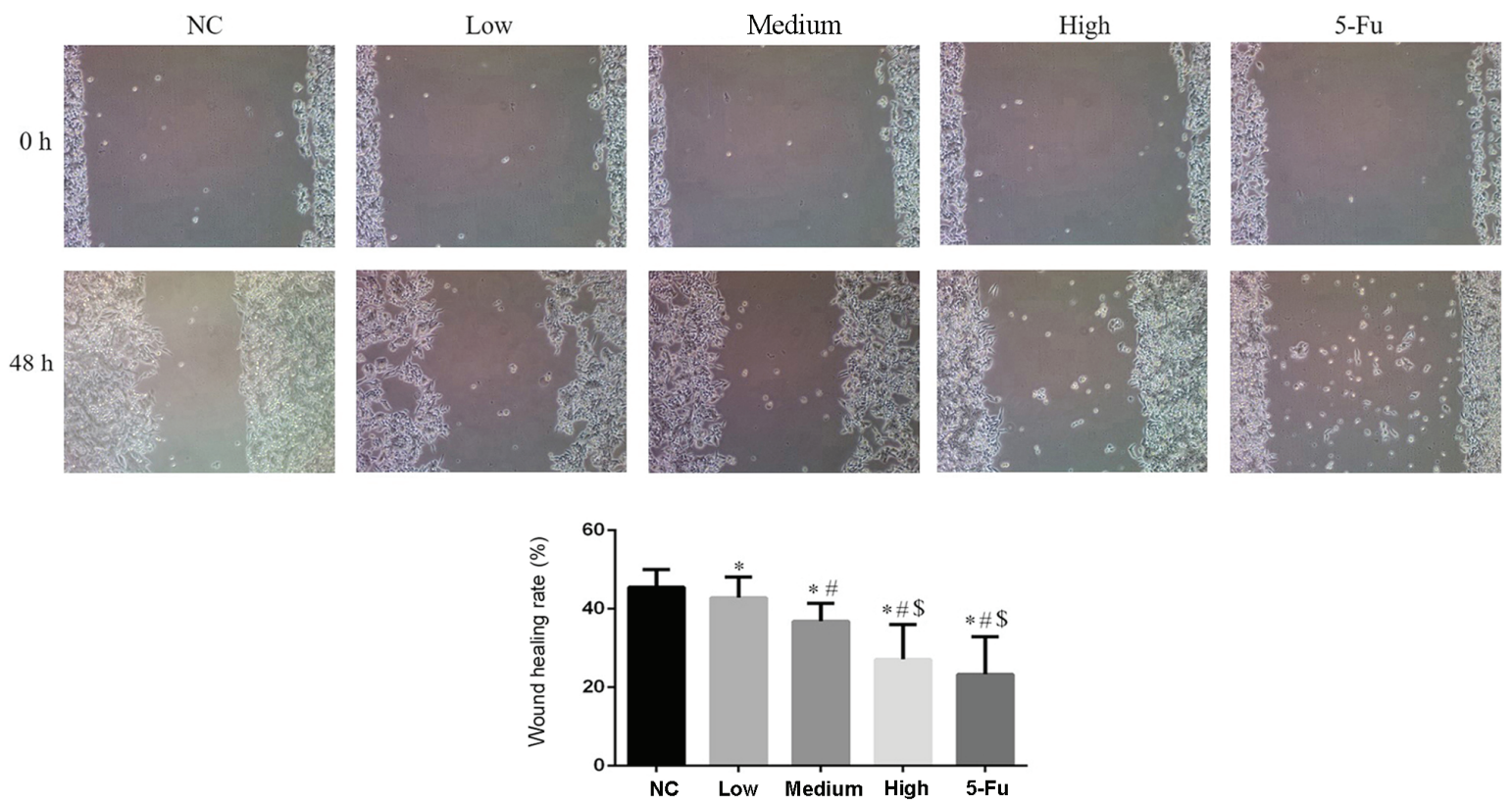

Figure 5. Wound healing rate of different groups. ${ }^{*} \mathrm{P}<0.05$ vs. the $\mathrm{NC}$ group; ${ }^{*} \mathrm{P}<0.05$ vs. the low group; ${ }^{\mathrm{S}} \mathrm{P}<0.05$ vs. the medium group. $\mathrm{NC}$, no-treatment control group; low, group treated with $10 \mu \mathrm{g} / \mathrm{ml} \mathrm{GA}$; medium, group treated with $50 \mu \mathrm{g} / \mathrm{ml} \mathrm{GA}$; high, group treated with $100 \mu \mathrm{g} / \mathrm{ml} \mathrm{GA}$; 5-Fu, group treated with $10 \mu \mathrm{g} / \mathrm{ml} 5$-fluorouracil; GA, gambogic acid.
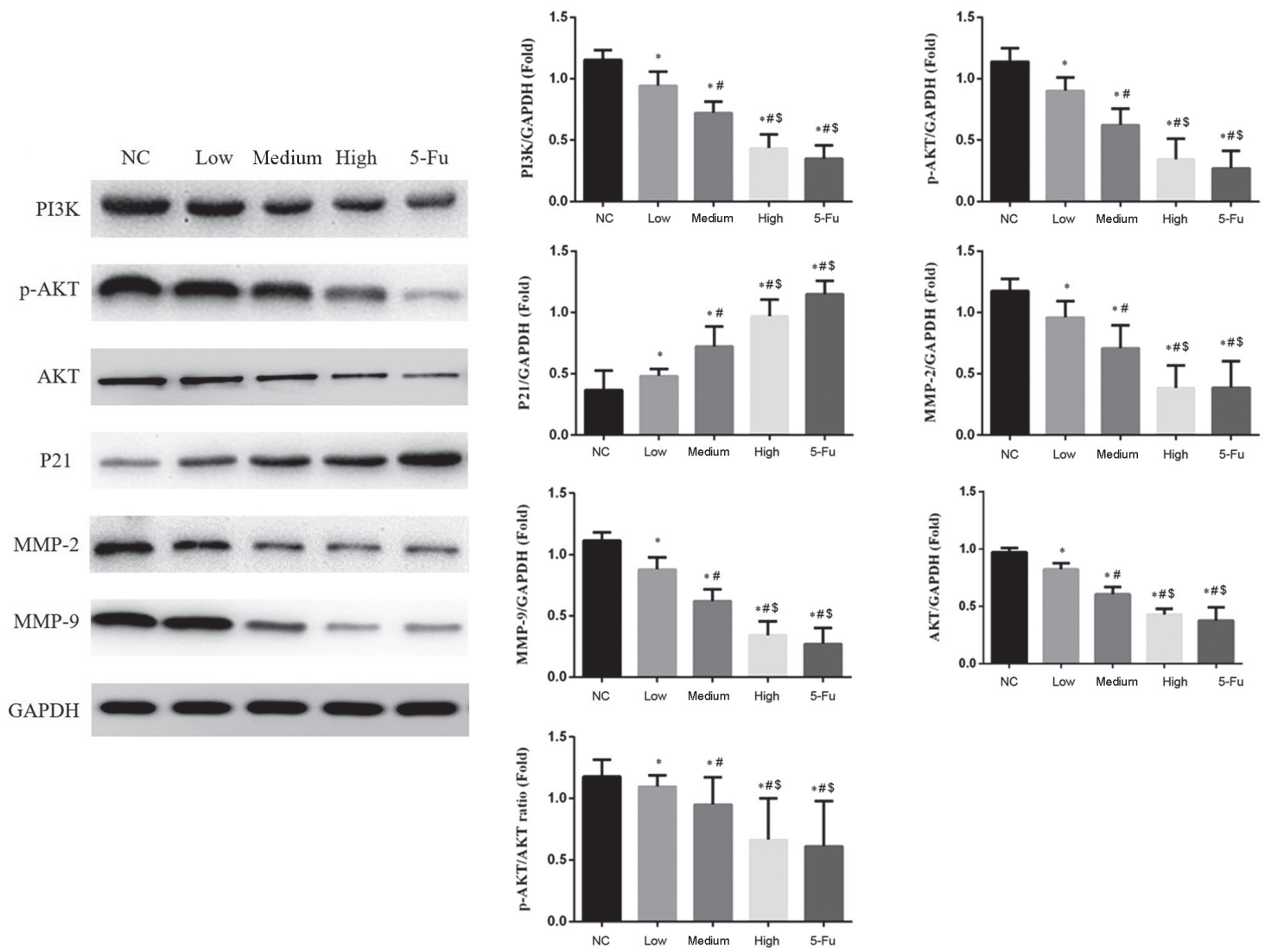

Figure 6. Relative protein expression levels in different groups. ${ }^{*} \mathrm{P}<0.05$ vs. the $\mathrm{NC}$ group; ${ }^{\sharp \mathrm{P}}<0.05$ vs. the low group; ${ }^{\$} \mathrm{P}<0.05$ vs. the medium group. $\mathrm{NC}$, no-treatment control group; low, group treated with $10 \mu \mathrm{g} / \mathrm{ml} \mathrm{GA}$; medium, group treated with $50 \mu \mathrm{g} / \mathrm{ml} \mathrm{GA}$; high, group treated with $100 \mu \mathrm{g} / \mathrm{ml} \mathrm{GA} ; 5-\mathrm{Fu}$, group treated with $10 \mu \mathrm{g} / \mathrm{ml}$ 5-fluorouracil; GA, gambogic acid; PI3K, phosphoinositide 3-kinase; AKT, protein kinase B; p-, phosphorylated; MMP, matrix metalloprotease.

group (all $\mathrm{P}<0.05$; Fig. 4). The number of invasive cells in the 5 -Fu group were significantly reduced when compared with the
$\mathrm{NC}$, low and medium groups (each, $\mathrm{P}<0.05$ ). Significant differences were also observed between GA-treated groups $(\mathrm{P}<0.05)$. 
GA affects cell migration. The wound healing rates of GA-treated groups were significantly inhibited compared with the NC group $(\mathrm{P}<0.05$; Fig. 5). The wound healing rate of the 5 -Fu group was significantly reduced compared with the $\mathrm{NC}$, low and medium groups. This effect was dose-dependent.

GA affects the PI3K/AKT pathway protein expression. Compared with the NC group, protein expression levels of PI3K, AKT, p-AKT, MMP-2 and -9 significantly decreased, and the expression levels of P21 significantly increased following treatment with GA at low, medium and high doses $(\mathrm{P}<0.05$; Fig. 6). Furthermore, the p-AKT/AKT ratio decreased in all GA-treated groups compared with the $\mathrm{NC}$ group and this effect was dose-dependent $(\mathrm{P}<0.05)$.

\section{Discussion}

GA is the main active ingredient in gamboge. In Traditional Chinese Medicine, GA is used to treat ulcers, swelling and poisoning $(15,16)$. Previous studies have revealed antitumor effects of GA, including induction of apoptosis, and inhibition of proliferation and pro-neoplastic protein expression (17-20). GA was determined to selectively kill cancer cells without affecting normal hematopoietic cells (21). Previous studies revealed that GA exhibited antitumor effects in colon cancer, however, the underlying mechanism of action remains unclear $(22,23)$. In the present study, GA exhibited antitumor effects by inhibiting cell proliferation, invasion and migration and increasing apoptosis. Furthermore, GA arrested cells in the G1 phase of the cell cycle. At present, 5-Fu is the preferred drug for the clinical treatment of tumors. Therefore, 5-Fu was used as a positive control in the present study.

The PI3K/AKT signaling pathway is activated in the majority of tumors $(24,25)$, which further enhances tumor-associated cell activity, including proliferation, invasion and migration (25). In the current study, GA inhibited the expression of PI3K, AKT and p-AKT in human colon cancer SW620 cells. Furthermore, the ratio of p-AKT to AKT decreased significantly following treatment with GA indicating that inhibition of the AKT-associated signaling may mediate the antitumor activity of GA. P21 is an important protein, which is downstream of AKT, that serves as a suppressor of tumor development (26) and can prevent cells from exiting the G1 phase (27-29). In the current study, following treatment with GA, the protein expression of P21 increased along with a dose-dependent increase in the number of cells in the G1 phase of the cell cycle.

Migration of cancer cells from the primary tumor and subsequent invasion through the tissue barrier is key to metastasis $(30,31)$. Extracellular matrix and basement membranes are a natural barrier in the process of tumor infiltration and diffusion, and MMPs that degrade the matrix are important for promoting tumor invasion and metastasis $(32,33)$. Previous studies indicated that MMP-2 and -9 increase cancer cell invasion and migration and are the downstream gene targets in the PI3K/AKT pathway $(34,35)$. The present results suggest that GA suppressed SW620 cell invasion and migration, and regulated the MMP-2 and -9 protein expression via downregulation of the PI3K/AKT signaling pathway. GA appeared to suppress SW620 cancer cell pro-neoplastic and pro-metastatic activities, including proliferation, invasion and migration, by altering the PI3K/AKT/P21 signaling and MMP-2 and -9 activity in vitro.

The current study was limited by the use of a single cell line and lack of in vivo experiments. In future studies, the effects of GA should be investigated in different colon cancer cell lines and in vivo.

\section{Acknowledgements}

Not applicable.

\section{Funding}

No funding was received.

\section{Availability of data and materials}

The datasets used and/or analyzed during the present study are available from the corresponding author on reasonable request.

\section{Authors' contributions}

$\mathrm{ZZ}$ designed the current study, acquired/analyzed the data and drafted the manuscript. JM designed the current study, acquired the data and revised the manuscript.

\section{Ethics approval and consent to participate}

Not applicable.

\section{Patient consent for publication}

Not applicable.

\section{Competing interests}

The authors declare that they have no competing interests.

\section{References}

1. Siegel RL, Miller KD and Jemal A: Cancer statistics, 2016. CA Cancer J Clin 66: 7-30, 2016.

2. Bernadach M, Lapeyre M, Dillies AF, Miroir J, Moreau J, Kwiatkowski F, Pham-Dang N, Saroul N, Durando X and Biau J: Toxicity of docetaxel, platine, 5-fluorouracil-based induction chemotherapy for locally advanced head and neck cancer: The importance of nutritional status. Cancer Radiother 23: 273-280, 2019 (In French).

3. Zu M, Ma L, Zhang X, Xie D, Kang Y and Xiao B: Chondroitin sulfate-functionalized polymeric nanoparticles for colon cancer-targeted chemotherapy. Colloids Surf B Biointerfaces 177: 399-406, 2019.

4. Ishaq M, Khan MA, Sharma K, Sharma G, Dutta RK and Majumdar S: Gambogic acid induced oxidative stress dependent caspase activation regulates both apoptosis and autophagy by targeting various key molecules (NF- $\mathrm{B}$, Beclin-1, p62 and NBR1) in human bladder cancer cells. Biochim Biophys Acta 1840: 3374-3384, 2014.

5. Wang $\mathbf{J}$ and Yuan Z: Gambogic acid sensitizes ovarian cancer cells to doxorubicin through ROS-mediated apoptosis. Cell Biochem Biophys 67: 199-206, 2013.

6. Wang S, Wang L, Chen M and Wang Y: Gambogic acid sensitizes resistant breast cancer cells to doxorubicin through inhibiting P-glycoprotein and suppressing survivin expression. Chem Biol Interact 235: 76-84, 2015. 
7. Huang W, Wang X, Shi C, Guo D, Xu G, Wang L, Bodman A and Luo J: Fine-tuning vitamin E-containing telodendrimers for efficient delivery of gambogic acid in colon cancer treatment. Mol Pharm 12: 1216-1229, 2015.

8. Danielsen SA, Eide PW, Nesbakken A, Guren T, Leithe E and Lothe RA: Portrait of the PI3K/AKT pathway in colorectal cancer. Biochim Biophys Acta 1855: 104-121, 2015.

9. Polivka J Jr and Janku F: Molecular targets for cancer therapy in the PI3K/AKT/mTOR pathway. Pharmacol Ther 142: 164-175, 2014.

10. Faes S and Dormond O: PI3K and AKT: Unfaithful partners in cancer. Int J Mol Sci 16: 21138-21152, 2015.

11. Chang YL, Zhou PJ, Wei L, Li W, Ji Z, Fang YX and Gao WQ: MicroRNA-7 inhibits the stemness of prostate cancer stem-like cells and tumorigenesis by repressing KLF4/PI3K/Akt/p21 pathway. Oncotarget 6: 24017-24031, 2015.

12. Zheng L, Zhang Y, Liu Y, Zhou M, Lu Y, Yuan L, Zhang C, Hong $\mathrm{M}$, Wang $\mathrm{S}$ and $\mathrm{Li} \mathrm{X}$ : MiR-106b induces cell radioresistance via the PTEN/PI3K/AKT pathways and p21 in colorectal cancer. J Transl Med 13: 252, 2015.

13. Zhou R, Xu L, Ye M, Liao M, Du H and Chen H: Formononetin inhibits migration and invasion of MDA-MB-231 and 4T1 breast cancer cells by suppressing MMP-2 and MMP-9 through PI3K/AKT signaling pathways. Horm Metab Res 46: 753-760, 2014.

14. Li W, Liu Z, Zhao C and Zhai L: Binding of MMP-9-degraded fibronectin to $\beta 6$ integrin promotes invasion via the FAK-Src-related Erk1/2 and PI3K/Akt/Smad-1/5/8 pathways in breast cancer. Oncol Rep 34: 1345-1352, 2015.

15. Fu Q, Li C and Yu L: Gambogic acid inhibits spinal cord injury and inflammation through suppressing the p38 and Akt signaling pathways. Mol Med Rep 17: 2026-2032, 2018.

16. Wu X, Long L, Liu J, Zhang J, Wu T, Chen X, Zhou B and Lv TZ Gambogic acid suppresses inflammation in rheumatoid arthritis rats via PI3K/Akt/mTOR signaling pathway. Mol Med Rep 16: 7112-7118, 2017

17. Duan D, Zhang B, Yao J, Liu Y, Sun J, Ge C, Peng S and Fang J: Gambogic acid induces apoptosis in hepatocellular carcinoma SMMC-7721 cells by targeting cytosolic thioredoxin reductase Free Radic Biol Med 69: 15-25, 2014.

18. Shi X, Chen X, Li X, Lan X, Zhao C, Liu S, Huang H, Liu N, Liao S, Song W, et al: Gambogic acid induces apoptosis in imatinib-resistant chronic myeloid leukemia cells via inducing proteasome inhibition and caspase-dependent Bcr-Abl downregulation. Clin Cancer Res 20: 151-163, 2014.

19. Wang LH, Yang JY, Yang SN, Li Y, Ping GF, Hou Y, Cui W, Wang ZZ, Xiao W and Wu CF: Suppression of NF- $\kappa$ B signaling and P-glycoproteins function by gambogic acid synergistically potentiates adriamycin-induced apoptosis in lung cancer. Curr Cancer Drug Targets 14: 91-103, 2014.

20. Chi Y, Zhan XK, Yu H, Xie GR, Wang ZZ, Xiao W, Wang YG, Xiong FX, Hu JF, Yang L, et al: An open-labeled, randomized, multicenter phase II a study of gambogic acid injection for advanced malignant tumors. Chin Med J (Engl) 126: 1642-1646, 2013.

21. Wang $X$ and Chen W: Gambogic acid is a novel anti-cancer agent that inhibits cell proliferation, angiogenesis and metastasis. Anticancer Agents Med Chem 12: 994-1000, 2012.

22. Wei F, Zhang T, Yang Z, Wei JC, Shen HF, Xiao D, Wang Q, Yang P, Chen HC, Hu H, et al: Gambogic acid efficiently kills stem-like colorectal cancer cells by upregulating ZFP36 expression. Cell Physiol Biochem 46: 829-846, 2018.
23. Gao G, Bian Y, Qian H, Yang M, Hu J, Li L, Yu L, Liu B and Qian X: Gambogic acid regulates the migration and invasion of colorectal cancer via microRNA-21-mediated activation of phosphatase and tensin homolog. Exp Ther Med 16: 1758-1765, 2018.

24. Toren P and Zoubeidi A: Targeting the PI3K/Akt pathway in prostate cancer: Challenges and opportunities (review). Int J Oncol 45: 1793-1801, 2014.

25. Chen J, Shao R, Li F, Monteiro M, Liu JP, Xu ZP and Gu W: PI3K/Akt/mTOR pathway dual inhibitor BEZ235 suppresses the stemness of colon cancer stem cells. Clin Exp Pharmacol Physiol 42: 1317-1326, 2015.

26. Lu S, Ren C, Liu Y and Epner DE: PI3K-Akt signaling is involved in the regulation of $\mathrm{p} 21$ (WAF/CIP) expression and androgen-independent growth in prostate cancer cells. Int J Oncol 28: 245-251, 2006.

27. Yeo D, He H, Baldwin GS and Nikfarjam M: The role of p21-activated kinases in pancreatic cancer. Pancreas 44: 363-369, 2015.

28. Wei CY, Tan QX, Zhu X, Qin QH, Zhu FB, Mo QG and Yang WP: Expression of CDKN1A/p21 and TGFBR2 in breast cancer and their prognostic significance. Int J Clin Exp Pathol 8: 14619-14629, 2015.

29. Li J, Li Z, Kan Q, Sun S, Li Y and Wang S: Association of p21 3'UTR gene polymorphism with cancer risk: Evidence from a meta-analysis. Sci Rep 5: 13189, 2015.

30. Nakayama H, Ohuchida K, Yonenaga A, Sagara A, Ando Y, Kibe S, Takesue S, Abe T, Endo S, Koikawa K, et al: S100P regulates the collective invasion of pancreatic cancer cells into the lymphatic endothelial monolayer. Int J Oncol 55: 211-222, 2019.

31. Kapali AS, George NA, Iype EM, Thomas S, Varghese BT, Balagopal PG and Sebastian P: Retrospective outcome analysis of Buccal mucosal and lower alveolar squamous cell carcinoma from a high-volume tertiary cancer Centre. Indian J Surg Oncol 10: 286-291, 2019.

32. Iochmann S, Bléchet C, Chabot V, Saulnier A, Amini A, Gaud G, Gruel Y and Reverdiau P: Transient RNA silencing of tissue factor pathway inhibitor-2 modulates lung cancer cell invasion. Clin Exp Metastasis 26: 457-467, 2009.

33. Safranek J, Pesta M, Holubec L, Kulda V, Dreslerova J, Vrzalova J, Topolcan O, Pesek M, Finek J and Treska V: Expression of MMP-7, MMP-9, TIMP-1 and TIMP-2 mRNA in lung tissue of patients with non-small cell lung cancer (NSCLC) and benign pulmonary disease. Anticancer Res 29: 2513-2518, 2009.

34. Yuan H, Yang P, Zhou D, Gao W, Qiu Z, Fang F, Ding S and Xiao W: Knockdown of sphingosine kinase 1 inhibits the migration and invasion of human rheumatoid arthritis fibroblast-like synoviocytes by down-regulating the PI3K/AKT activation and MMP-2/9 production in vitro. Mol Biol Rep 41: 5157-5165, 2014.

35. Fan Z, Duan X, Cai H, Wang L, Li M, Qu J, Li W, Wang Y and Wang J: Curcumin inhibits the invasion of lung cancer cells by modulating the PKC $\alpha /$ Nox-2/ROS/ATF-2/MMP-9 signaling pathway. Oncol Rep 34: 691-698, 2015.

This work is licensed under a Creative Commons Attribution-NonCommercial-NoDerivatives 4.0 International (CC BY-NC-ND 4.0) License. 